\title{
A REVIEW ON SEAFOODS AND THEIR PRESERVATION TECHNIQUES
}

\author{
M . Dhilipkumar \\ Student, Department of Food Technology \\ JCT College of Engineering and Technology, \\ Coimbatore, Tamilnadu, India
}

\author{
S.Sangeetha Gandhi \\ Assistant Professor, Department of Food Technology, \\ JCT College of Engineering and Technology, \\ Coimbatore, Tamilnadu, India
}

\author{
R. Karthika \\ Student, Department of Food Technology \\ JCT College of Engineering and Technology, \\ Coimbatore, Tamilnadu, India
}

\begin{abstract}
Sea foods products are highly traded foods and it is a healthy food choice. It is a low-fat protein source which provides long chain omega-3 fatty acids significant for early development along with ear, eye, kidney and heart health. It has been regarded as a good source of various nutritional compounds such as vitamin-D, proteins, PUFA like omega-6, iodine, calcium etc. These are having high water content with neutral $\mathrm{pH}$. Sea food consumption is associated with neurological development during gestation time and childhood and reduce mortality from heart diseases. Due to utilization of aquatic resources and growth of population of humans, it is desirable to efficiently recover proteins, minerals and vitamins from marine foods and marine byproducts. Sea food consumption in worldwide is increasing because of its advances in aquaculture and the presumed nutritional benefits of sea foods products. The fresh foods and marine foods's has increasing overall growth worldwide after drinkable healthy soups and grade third among the various categories of sea food products. Oxidation and microbial growth are the major causes for spoilage of marine food products. Consumption of sea foods prevents many eye related diseases age related cognitive decline. . However, benefits may vary by nutrient content in different sea food types like carp, cray, crab, shrimp, eel, etc. So there is a strictly need of studying various food preservation techniques like ozone treatment, Phage treatment, organic treatment, Modified atmospheric packaging technique etc. This review focuses on the preservation techniques and seafood classification which are related with the shelf life of sea food products and helps to prevent safe, nutritive, additive free foods with low level of processing and preservation.
\end{abstract}

Keywords - Seafoods, health, nutrition, preservation, shelf life

\section{INTRODUCTION}

Sea foods had been a favorite food for many people. Sea foods are not only tasty, but it also cure various diseases as it is full of nutritious elements. Over the past 30 years, sea food consumption underwent a major choice. In the year 2009, aquaculture and capture fisheries supplied more than 100 million tons of fishery products around the world, approximately 70-75 million tons of which were for human consumption [1]. Seafood consumption is associated with improved neurological development during gestation and childhood and more tenuously linked to reduce mortality from Coronary artery disease. Due to utilization of aquatic resources and growth of population of humans, it is desirable to efficiently recover proteins, minerals and vitamins from marine foods and marine byproducts. Worldwide consumption of sea foods is increasing because of its uses in marine resources and nutritional benefits of sea foods [2]. The fresh foods and marine foods's has increasing overall growth worldwide after drinkable healthy soups and grade third among the various categories of sea food products. Oxidation and microbial growth are the major causes for spoilage of seafood products [3]. Consumption of sea foods prevents many eye related diseases age related cognitive decline. Sea food consumption varied by more than 100- fold between differences of areas of the world as well as between coastal regions of countries. Over the past 15 years, the food security of seafood has been improved due to the technological development in processing, preservation, storage and marketing. So there is a strictly need of studying various food preservation techniques like Ozone treatment, Natural organic treatment, MAP technique, Phage treatment etc. This paper includes a review on introduction to sea foods, classification and preservation techniques which are related with extension of shelf life of sea food products. 


\section{International Journal of Engineering Applied Sciences and Technology, 2020 Vol. 5, Issue 7, ISSN No. 2455-2143, Pages 75-82 \\ Published Online November 2020 in IJEAST (http://www.ijeast.com)}

\section{CLASSIFICATION}

Seafood is any form of sea life regarding as food by humans and they divided into three major categories such as Fish, Shellfish and Crustaceans. These categories of seafood has been classified into many types,

\section{Anchovy}

Anchovy are small, common salt water forage fish which belongs to the family Engraulidae that are used as food for humans. These foods have more nutritional content and valuable for providing high quality of protein better than those of meat products [4]. However, they are most perishable of all of the foods because their suitable medium for growth of microorganisms after death.

\section{Bass}

Bass (Dicentrarchus labrax) is an economically important fish in the tropical and subtropical regions of Asia and Pacific [5]. Like other fishes, Bass are rich in protein and Omega-3s and are a good source of Phosphorus, Manganese and Vitamin B12.

\section{Blue fish}

Blue fish (Pomatomus Saltatrix) is a semi fat seafood and more perishable when commercialized in its fresh form and under tropical temperature, it becomes rotten rapidly, so its preservation techniques are need to increase its quality. It is the only extant species of family Pomatomidae and it is a good source of Magnesium and Potassium [6].

\section{Carp}

Carp (Cyprinus Carpio) are various species of oily freshwater fish which belongs to the family Cyprinidae [7]. These are the great source of many nutritionally important substances particularly Omega- 3 fatty acids. These unsaturated acids contribute to increase in prevention of heart attack.

\section{Cray fish}

Cray fish (Cambarus sp.) are eaten all over the world. Like other Cray fishes, only a small portion of the body of Cray fish is edible [8]. The tail portion of the Cray fish is used for preparing dishes and soups.

\section{Char}

It is a genus of salmonid fish which belongs to the family Salmonidae. Most of the Char fish may be identified by pink, light cream, red spots in a darker body [9]. These are the good source of forgotten Selenium.

\section{Cod}

Cod fish (Gadus Morhua) belongs to the family Gadidae. It is a low fat source of protein, making it an excellent choice for people and improve their heart health [10].

\section{Flounder}

Flounders (Paralinchtys dendatus) are a group of flatfish species and they reduce the risk of heart disease [11].

\section{Haddock}

Haddock (Melanogrammus aeglefinnus) is also known as Sea haddock mostly lives in salt water which belongs to the family Gadidae. It slows down the formation of cancer as well as tumors [12]. It lowers the LDL cholesterol.

\section{Halibut}

Halibut is originated from the regions of North Pacific and Bering sea [13]. It reduces fatigue and enhance immunity.

\section{Herring}

Herring (Clupea harengus) are forage fish which belongs to the family Clupeidae. It has been a staple food source and the fish is used as eaten raw, fermented, pickled or cured by smoking [14].

\section{Salmon}

Salmon (Salmo Salar) is the common name of several species of ray finned fish that belongs to the Salmonidae family. It is an oily fish with high content of Omega-3 fatty acids and proteins. [15].

\section{Trout}

Trout (Oncorhynchus mykiss) are closely related to the fish such as Salmon and Char. It is also a good source of Iodine [16].

\section{Tuna}

It is a salt water fish that belongs to the Scombridae family. It contains all essential amino acids which is required by the body for maintenance and growth of lean muscle tissue [17].

\section{Crab}

These are decaped crustaceans of infraorder Brachyura usually hidden entirely under the throax. Crab meat is a meat which is found within a crab. Crab meat is low in fat and contains around $80 \mathrm{KCal}$ per $85 \mathrm{~g}$ serving [18]. These are delicious seafood that many people enjoy by themselves during a feast or when made into salads, soups, cakes etc. It reduces inflammation and plague in our neural pathways.

\section{Lobster}

Lobsters are a family of large marine Crusteceans which belongs to the family Nephropidae. It can be eaten as a sandwich filler, or added to dishes like Pasta, egg filler and mashed potatoes [19].

\section{Prawn}

Prawn is a small aquatic Crusteceans with an exoskeleton and ten legs some of which can be eaten [20]. These are a good source of vitamin B12 and Niacin, that helps our body to produce energy, build muscle and replenish RBC.

\section{Shrimp}




\section{International Journal of Engineering Applied Sciences and Technology, 2020 \\ Vol. 5, Issue 7, ISSN No. 2455-2143, Pages 75-82 \\ Published Online November 2020 in IJEAST (http://www.ijeast.com)}

Shrimps are decomposed Crusteceans with elongated bodies and a primarily swimming mode of location. They play important roles in food source for larger animals ranging from fish to whales [21].

\section{Abalone}

It is common name for any of the group of small to large marine gastroped molluscs, sea snails that belongs to the family Haliotidae. Abalone not only tastes great, but also an excellent source of many vital nutrients [22]. They can reduce the risk of heart disease.

\section{Clams}

Clam is a type of shellfish and mostly found in Saltwater. They belongs to the family Veneridae. Clams are a very nutritious food and promote sexual health. They have been found to possess cancer preventing properties [23].

\section{Conch}

Conch (Strombus gigas) is a common name of number of various medium -to big sized sea shells and snails. It belongs to the family Strombidae [24]. Conch meat is consumed marinated, minced raw and copped in many dishes such as soups, stew, salads and local recipes.

\section{Mussels}

Mussels (Mytilus edulis) is the common name used for members of several families of bivalve molluscs, and mostly found in salt water. It belongs to the family Unionidae. Mussels contribute to circulate health and energy levels [25]. They improving brain function and reducing inflammatory conditions such as arthritis.

\section{Oysters}

Oysters are a common name for different families of seawater bivalve molluscs. They are found in marine water [26]. They are low in calories yet looked with nutrients including proteins, fats, vitamins and minerals.

\section{Scallops}

Scallops are a type of bivalve molluscs, meaning the interior mussel is surrounded by two shells, similarly to oysters, mussels and clams [27]. They promote blood vessel relaxation, enable good $\mathrm{r}$ blood circulation. and helps blood pressure control.

\section{Escargot}

Escargot (Helix pomatia) is a dish containing of cooked edible land snails [28]. They boost the immune system due to their antioxidants and anti inflammatory effects and they have anticancer properties.

\section{Squid}

Squid is generally reffers to a battered and deep-fried appetizer which is served in bars and restaurents through some people use it interchangeably with major ingredients [29].

\section{Sturgeon}

It is the common name for 27 species of fish type that belongs to the Acipenseridae family. It is a fish famous for its carrier which is considered as one of the world's top three delicacies [30]. It has white meat that is light in color and has no small bones, making it to easy to eat.

\section{Eels}

Freshwater eels are abundant and greatly valued as food, are of major economic importance [31].It belongs to the family Anguillidae. Eel enhances the development of brain, good eye sight and functions of nervous system.

\section{Winkles}

Winkle (Littorina littorea) or periwinkle is a species of small edible wherk or sea snails that belongs to Littorinidae family. It contributes to our thyroid health, energy needs and nervous system and promotes the growth of children [32].

\section{Sardine}

Sardine (Sardina Pilchardus) are Pilchard are common names that refers to various small, oily forage fish which belongs to the family Clupeidae. These are an excellent source of EPA and DHA, which are two fatty acids and to reduce inflammation [33].

\section{Snappers.}

It is important food fish that belongs to the family Lutjanidae. The nutrients in snappers increase the absorption of food to the blood stream and many other organs, leaving yon with smooth and healthy digestion and decrease risk of stomach problems [34].

\section{TYPES}
i. Cubera snapper
ii. Lane snapper
iii. Mangrove snapper
iv. Queen snapper
v. Red snapper
vi. Vermilion snapper
vii. Yellow tail snapper.

\section{BIOACTIVE COMPONENTS DERIVED FROM SEA FOODS}

\section{Protein, Peptide AND NON PRotein Nitrogen COMPOUNDS.}

Sea food consumption provides health benefits to growing children and adolescents. There is a possibility that the health function of fish - based foods is not simply related to DHA and EPA. There is a good deal of research that is focused on the efficacy of DHA and EPA in sea food products for human health, whereas there is almost none related to the health effects of vitamins, minerals and proteins 


\section{International Journal of Engineering Applied Sciences and Technology, 2020 \\ Vol. 5, Issue 7, ISSN No. 2455-2143, Pages 75-82 \\ Published Online November 2020 in IJEAST (http://www.ijeast.com)}

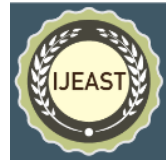

[35]. Sea food proteins possess good amino acid scores and digestible characteristics. They constitute approximately 15$20 \%$ of sea foods and it can be classified as myobribillar, sacroplasmic and stroma types. In many studies, compared with animal proteins, lowers the highly sensitive $\mathrm{C}$ - reactive protein concentration in serum and improved sensitivity of insulin in resistant individuals. Marine bioactive peptides have beneficial effects such hypoholesterolomia, immunomodulating, and antimicrobial effects. Non proteins nitrogen compounds (NPN) compounds are also present to various extends depending on the species, NPR compounds are composed nucleotides, amino acids, amines and their breakdown products, ammonium salts and urea [36].

\section{Phospolipids}

Among the seafood products, $10-15 \%$ of fats consists of phospholipids. Phospholipids can decrease blood total lipids and improve brain function. As phospholipids derived from marine foods, DHA and EPA, which have a good potential as functional food ingredients are abundant. They have been several human studies that have investigated the effect of supplementation with dietary krill oil, which as contains n-3 PUFA's (PL) rather than n-3 PUFA's (TG) [37]. This results shows that krill oil supplementation was tolerated and caused desirable increases in plasma and cell membrane. It has suggested that PL containing $n$ - PUFA 's derived from squid muscle decreased serum and liver TG cholesterol levels compared with that induced by soybean PL or TG containing n-3 PUFA's

\section{3. n-3 PUFA's}

The beneficial effects of seafoods have primarily been attributed to n-3 PUFA's such as DHA and EPA. Marine organisms have been identified as the foods that contain more amount of the fatty acids. The proportion of $n-3$ PUFA's in muscles of fish is higher in fatty fish such as herring and salmon than in lean fish such as cod and haddock. Shell fish such as shrimp, crab and lobster have small amount of n-3 PUFA's. In a marine model of insulin resistance and obesity, dietary n-3 PUFA's were incorporated in the phospholipids; it enhanced the membrane affinity and fluidity and some of insulin receptors as well as glucose transporters protein levels in adipose tissue [38]. In addition n-3PUFA's have been good beneficial effects on adipose tissue in obese individuals through reduced body fat mass and oxidation of lipids, body weight improvement, inflammation, rheumatoid arthritis, Crohn's disease and immunoglobulin.

\section{Taurine}

Taurine (2-amino ethane sulfonic acid) is present in all tissues. It is particularly abundant in blood, brain and heart, Taurine's synthetic activity is weaker than in guinea -pigs and rats. It is a non essential but conditionally essential amino acids present in our human body. It has many important roles in essential biological process such as bile acid conjugation, calcium modulation, immunity and membrane stabilization [39]. It has beneficial anti-hypercholesteronic, antihypertensitive and anti-inflammatory effects on life style related diseases.

\section{Carotenoids.}

These are fat soluble and they have brilliant yellow and orange pigments. One of the most important biological functions of carotenoids such as beta carotene in human body is their ability to form vitamin A. Other carotenoids such as astaxanthin, lycopene and fucoxanthin do not forms vitamin A. Fu coxanthin is a carotenoid which is in orange color found in edible brown seaweeds. It prevents the growth of fat tissue, reduces abdominal fat and reduces abdominal fat and reduces the risk of stroke, cancers and inflammations [40].

\section{Fibers}

Seafood contains small amount of carbohydrate and fiber content. Edible seaweed contains a low dietary fiber and water soluble fiber constitutes $60-80 \%$ [41]. Seaweeds are classified into three main groups, Red seaweeds have phycocyanin, contains agars and carrageenans as the primary polysaccharides. Green seaweeds are green due to the presence of chlorophyll, which is a major polysaccharide components. Brown seaweeds have primary polysaccharides such as cellulose, fucans and alginates. In animal studies, polysaccharides extracted from different edible seaweeds have to reduce LDL cholesterol and in plasma.

\section{PRESERVATION TECHNIQUES}

\section{OZONE TREATMENT}

Ozone treatment is one of the most powerful oxidizing and sanitizing treatments. It is either by gaseous form or dissolved form. It oxidize many cellular components leading to leakage of membrane and call death, it has more antibiotic activity which requires short contact times and it takes place at the level of aquaculture and marine reesources. For an example, applying $0.07 \mathrm{mg} / \mathrm{L}$ of ozone by directly to marine water, Prawn hatcheries has been shown to allow the survival of prawn, but eliminate pathogenic vibrios. Generally, seafood spoilage based on several metrics including level of bacteria and gases produced from seafood breakdown such as Trimethylamine Nitrogen (TVB-N), Total Viable Nitrogen (TVN-N) Total Volatile Acid [TVA] [42]. These methods are equivalent, but each has a high level of consensus when the seafood product is spoiled.

\section{Advantages:}

$\mathrm{O}_{3}$ increases the shelf life of seafood products. $\mathrm{O}_{3}$ reduces the 1 contamination of fish as well as formation of volatile $\mathrm{N}_{2}$ compounds. It do not produce any toxic residue.

\section{PHAGE TREATMENT}

Two different phage groups have shown promise to control the bacteria Vibrio.parahaemolyticusin raw oysters: a siproviridae phage VPp1a and $\mathrm{pVp}-1$ isolated from these bacteria. In this technique, Depuration process is used to 


\section{International Journal of Engineering Applied Sciences and Technology, 2020 \\ Vol. 5, Issue 7, ISSN No. 2455-2143, Pages 75-82 \\ Published Online November 2020 in IJEAST (http://www.ijeast.com)}

treated the foods. Depurationis a control process. Before feeding, Molluscs are held in potable water that has been treated with Ultra violet light, Ozone, Chlorine, for 1-2 hrs. This method is effective in removing coliform counts. Whle, it is carried out at minimum temperature and for a period of days, Depuration is not effective to protect against vibrios. However, Depuration in the presence of VPp1a phage was able to reduce the bacteria Vibrio.parahaemolyticus concentrations by $2.32-2.81 \log \mathrm{CFU} / \mathrm{g}$ at $15-18^{\circ} \mathrm{C}$ for 3 days. The $\mathrm{pVp}-1$ phage was investigated for its ability to eliminate the bacterial contamination as applied directly to contaminated oyster meat. Both application strategies resulted in decreases in Vibrio.parahaemolyticus population, bath immersion treatment is used to reduce the bacterial counts from $8.8 \times 10^{5} \mathrm{CFU} / \mathrm{g}$ after 3 days. Although, direct application of phage to contaminated meat almost eliminated contamination within $11 \mathrm{hr}$ at $15-19^{\circ} \mathrm{C}$, with $1.66 \times 10^{4} \mathrm{CFU} / \mathrm{g}$ in the treated samples. Although, sea foods present multiple challenges for this treatment, the large surface area, when applied on in shell oysters, short contact time bacterial targets and phage particles [43].

\section{NATURAL ORGANIC TREATMENT}

Seafoods are preserved naturally by adding organic acids, essential oils and tea polyphenols. It has been suggested to extend shelf life and maintains a synthetic preservative free marketing status. Essential oils such as oregano, thyme, turmeric and shallots have been shown to decrease the non - pathogenic spoilage bacteria levels in seafood products. A variety of polyphenols includin epigallocatechin gallate (EGCG), Catechins, epicatechin gallate, epigallacatechin and epicatechin. These polyphenols can be extracted from tea and have been shown to have antioxidants and antimicrobial properties. For example, Shrimp in a $0.02 \%$ of catechin solution for $12-15$ minutes slowed the growth of bacterial spoilage, reduced the count of Enterobacteriaceae. It had other quality enriching effects on the Prawn such as melanosis and reducing lipid oxidation. In this treatment, Dipping of dried- seasonal jumbo squid in a mixed tea phenol solution also showed a protective against loss of moisture, lipid oxidation and spoilage of bacteria. This treatment has shown to have a synergistic effect when combined with ozone treatment to extend its shelf life and reduce lipid oxidation. Citric acid have been shown to reduce growth of spoilage organisms in fresh shucked oyster sample; in addition, dippling treatments of oysters in citric acid showed a reduction of potentially pathogenic Vibrio.vulnificus below the deduction level of $2 \mathrm{log} / \mathrm{g}$ from artificially inoculated concentrations of $5 \mathrm{log} / \mathrm{g}$ [44].

\section{HIGH PRESSURE PROCESSING}

This treatment is used at a range at 200 to $700 \mathrm{Mpa}$, as an alternative to Thermal processing. Particular attention has been paid to the ability of High Pressure Processing to reduce Vibrio parahaemolyticus and Vibrio vulnificus in oyster samples.. Considerable differences in pressure resistance between V.parahaemolyticus is difficult. Differences of log reductions in V.parahaemolyticus is based on several processing temperature and time and whether a whole shelled reductions, pressure and processing time, HPP appears to be more effective against V.parahaemolyticus when carried out $2.0^{\circ} \mathrm{C}$ from $20^{\circ} \mathrm{C}$, the processing time can be lowered from 15 to 10 minutes and the pressure can be lowered to $200 \mathrm{Mpa}$ from $300 \mathrm{Mpa}$ without a loss in log reduction. The storage temperatures of seafood prior to HPP do not appear to affect resistance of $V$. parahaemolyticus to HPP. However, cold storage may increases the resistance of Vibro.vulnificus to this treatment by increases the PUFA \% in the cell membrane. After HPP treatment, post -HPP cold storage has been shown to cause additional reductions in cell number, which may occurs due to the inhibition of recovery of sub-lethally injured cells. This preservation technique is also used in Ham and rice products [45].

\section{Advantages:}

Easier and higher yield shucking and extraction of meat and fish products. Freshness of products and increase shelf life. Effective elimination of spoilage and pathogenic microorganisms. No impact on sensory, nutritional or functional properties.

\section{Limitations}

Increased metal fatigue, high cost equipment, long cycle terms.

\section{MODIFIED ATMOSPHERIC PACKAGING [MAP]}

A proportion of $\mathrm{CO}_{2}$ in thid treatment for marine products, above $25 \%$ and typically around $60 \%$, is effective in inhibiting the growth of aerobic bacteria. When carbon dioxide dissolves in water, it creates a weak acidic solution and the bacterial growth will slowly. $\mathrm{O}_{2}$ also helps to preserve the color of the fish products. However, to avoid rancidity in fatty fish, $\mathrm{O}_{2}$ is not required. Seafoods such as shrimp and prawns are packaged in an atmosphere, typically contains nitrogen and $\mathrm{CO} 2$. Under refrigerated conditions, shelf life of seafoods can be increased. This technique is also used fruits and vegetables, meat and poultry products etc., [46].

\section{IRRADIATION}

It is an oldest food preservation technique. Irradiation of food products has become an emerging technology with promising features to enhance the shelf life of many food products. It offers several characteristics including direct inactivation of organisms in typically frozen foods. The use of gamma irradiation and Xrays is to eliminate pathogenic strains of bacteria such as vibrios in oysters. It is popular alternative to thermal treatment [47]. This mechanism involves irradiation with high energy radiation leads to the breakdown of chemical bond and form free radicals an ions in microorganism, which leads their destruction. Its dosage rate is $2-8 \mathrm{kGy}$. In seafood products, we use the dosage levels of $3 \mathrm{kGy}$.

\section{ULTRASOUND PRESERVATION}




\section{International Journal of Engineering Applied Sciences and Technology, 2020 \\ Vol. 5, Issue 7, ISSN No. 2455-2143, Pages 75-82 \\ Published Online November 2020 in IJEAST (http://www.ijeast.com)}

Ultra sound preservation is composed of mechanical sound waves which is originate from molecular movements that oscillate in a propagation medium. These are similar to sound waves but, having a frequency above $16 \mathrm{kHz}$, cannot be deducted by the human ear. It produce intracellular cavitations, due to micro mechanical shock. It disrupts the cellular structural and functional components. This method is commonly used in fruit juices, dairy products and Sausages. The application of ultrasound have beneficial effects on different seafood process. Ultrasound waves; accelerating the heat transfer from the fluid to be gas,Cell destruction, Enzyme inactivation and drying filtration is used in cleaning surfaces, also; mixing and grinding process, the emulsification of fats and oils, to accelerate the freezing process, curing of fish and cleaning of homogenization. [48].

\section{Limitations}

Complex mode of action, Undesirable sensory changes, High energy consumption, Long treatment times.

\section{CONCLUSION}

Seafood preservation is a very important aspect of the fisheries. Here, we have presented a review of seafood classification and preservation techniques. Seafoods are the best sources of excellent proteins, vitamins, minerals and fats. This is evidence that the bioactive components derived from seafoods could have a good impact of the health of people around the world. Food preservation techniques extend shelf life of the products, while maintaining food quality and safety.

\section{REFERENCE}

[1] Fabinyi, M. (2012). Historical, cultural and social perspectives on luxury seafood consumption in China. Environmental Conservation, 39(1), 83-92.

[2] Guillen J, (2019) Natale F, Carvalho N, Casey J, Hofherr J, Druon JN, Fiore G, Gibin M, Zanzi A, Martinsohn JT. Global seafood consumption footprint. Ambio. 48(2):11122.

[3] Dalgaard P. (2003) Spoilage of seafood. InEncyclopedia of food science and nutrition (pp. 2462-2472). Academic Press.

[4] Ganias K, (2014) editor. Biology and ecology of sardines and anchovies. CRC Press;

[5] Gangan, S. S., Nirmale, V. H., Metar, S. Y., Yadav, B. M., Balange, A. K., Patil, S. D., ... \& Shingare, P. E. Local knowledge in Asian Sea Bass, Lates calcarifer (Bloch, 1790) culture in Raigad District of Maharashtra.

[6] Chesalin M, Al-Shajibi S, Zaki S, Al-Ghassani A, AlShagaa G. (2013) Biology and population dynamics of bluefish along Oman coast. InConference on Global Congress on ICM: Lessons Learned to Address New Challenges

[7] Khan MN, Shahzad K, Chatta A, Sohail M, Piria M, Treer T. (2016) A review of introduction of common carp
Cyprinus carpio in Pakistan: origin, purpose, impact and management. Croatian Journal of Fisheries. 1;74(2):7180.

[8] Kozák P, Ďuriš Z, Petrusek A, Buřič M, Horká I, Kouba A, Kozubíková-Balcarová E, Policar T, Němečková K. (2015) Crayfish biology and culture. University of South Bohemia in České Budějovice, Faculty of Fisheries and Protection of Waters;

[9] Power M, Reist JD, Dempson JB. (2008) Fish in highlatitude Arctic lakes. Polar lakes and rivers. 249-67.

[10] Cruz EF, da Cruz AM, Gomes R. (2019) Analysis of a traceability and quality monitoring platform for the fishery and aquaculture value chain. In 2019 14th Iberian Conference on Information Systems and Technologies (CISTI) 1-6.

[11] Lim HK, Kim YS, Son MH, Kim KD, Jeong MH, Chang YJ. (2012) Quality characteristics of starry flounder Platichthys stellatus meat reared in different salinity. Journal of Fisheries and Marine Sciences Education. 24(2):324-32.

[12] Fryer RJ, O'Neill FG, Edridge A. (2016) A meta-analysis of haddock size-selection data. Fish and Fisheries.17(2):358-74.

[13] Stoner AW, Ottmar ML. (2004)Fish density and size alter Pacific halibut feeding: implications for stock assessment. Journal of Fish Biology. 64(6):1712-24.

[14] Adeniyi OD. (2006)Herring fish (Clupea harengus) oil production and evaluation for industrial uses. Journal of dispersion science and technology.27(4):537-41.

[15]Espe M, Lemme A, Petri A, El-Mowafi A. (2006) Can Atlantic salmon (Salmo salar) grow on diets devoid of fish meal?. Aquaculture. 255(1-4):255-62.

[16] Hassan A, Ishaq M, Farooq A, Sadozai SH. (2007)Economics of trout fish farming in the northern areas of Pakistan. Sarhad journal of Agriculture. 23(2):407..

[17] Allain V, Pilling GM, Williams G, Harley S, Nicol S, Hampton J. (2016) Overview of tuna fisheries, stock status and management framework in the Western and Central Pacific Ocean. Fisheries in the Pacific. The Challenges of Governance and Sustainability. Cahiers du Credo. 19-48.

[18] Datta NC, Baguli TK, Mahapatra BK. (1999). Crab fishery resources in the coastal districts of West Bengal with special reference to cultural prospects of Scylla serrata (Forskal). Inland Fisheries Society of India. 93101.

[19] Radhakrishnan EV, Kizhakudan JK, Phillips BF. (2019) Introduction to Lobsters: Biology, Fisheries and Aquaculture. InLobsters: Biology, Fisheries and Aquaculture . Springer, Singapore.(pp. 1-33)

[20].Leu JH, Chen SH, Wang YB, Chen YC, Su SY, Lin CY, Ho JM, Lo CF. (2011)A review of the major penaeid shrimp EST studies and the construction of a shrimp 


\section{International Journal of Engineering Applied Sciences and Technology, 2020 \\ Vol. 5, Issue 7, ISSN No. 2455-2143, Pages 75-82 \\ Published Online November 2020 in IJEAST (http://www.ijeast.com)}

transcriptome database based on the ESTs from four penaeid shrimp. Marine Biotechnology. 1;13(4):608-21.

[21] Rahman MS, Rahman MM, Parvez MS, un Nabi MR. (2016) Feeding Habit and Length-weight Relationship of a Mudskipper Apocryptes Bato (Hamilton, 1822) from the Coast of Chittagong, Bangladesh. Journal of Bangladesh Academy of Sciences. 40(1):57-64.

[22] Kashiwada JV, Taniguchi IK. (2007) Application of recent red abalone Haliotis rufescens surveys to management decisions outlined in the California Abalone Recovery and Management Plan. Journal of Shellfish Research. 26(3):713-7

[23] Gaspar MB, Barracha I, Carvalho S, Vasconcelos P. (2012) Clam fisheries worldwide: main species, harvesting methods and fishing impacts. Clam fisheries and aquaculture. 291-327.

[24] Williamson DM, Proud WG. (2011) The conch shell as a model for tougher composites. International Journal of Materials Engineering Innovation. Jan 1;2(2):149-64.

[25] Eason CT, Adams SL, Puddick J, Romanazzi D, Miller MR, King N, Johns S, Forbes-Blom E, Hessian PA, Stamp LK, Packer MA. Greenshell ${ }^{\mathrm{TM}}$ (2018) Mussels: A Review of Veterinary Trials and Future Research Directions. Veterinary sciences. 5(2):36.

[26]Aji LP. (2011) A REVIEW OF PEARL OYSTER (Pinctada maxima) CULTUREIN GENERAL. Saintek Perikanan: Indonesian Journal of Fisheries Science and Technology. 6(2):85-91.

[27]Bergh O, Strand O. (2001) Great scallop, Pecten maximus, research and culture strategies in Norway: a review. Aquaculture International. 1;9(4):305-17.

[28]El-Khayat HM, Abdel-Hamid H, Mahmoud KM, Gaber HS, Taleb MA, Flefel HE. (2016) Snails and fish as pollution biomarkers in lake Manzala and Laboratory $\mathrm{C}$ : Laboratory exposed snails to chemical mixtures. International Journal of Agricultural and Biosystems Engineering. 10(11):741-52.

[29] Chavan AS, Satam SB, Pagarkar AU, Sharangdhar ST, Sharangdhar MT, Kulkarni GN, Gaikwad BV, Vishwasrao VV, Sawant SS.(2020) The Squid Processing: an important aspect in Indian Seafood Industry. . 799806.

[30] Mims SD, Lazur A, Shelton WL, Gomelsky B, Chapman F. (2002) Species profile: production of sturgeon. Southern Regional Aquaculture Center, Publication. 1-8.

[31] Van Ginneken VJ, Maes GE.(2005) The European eel (Anguilla anguilla, Linnaeus), its lifecycle, evolution and reproduction: a literature review. Reviews in Fish Biology and Fisheries. 1;15(4):367-98.

[32] Pulfrich A, Branch TA. (2002) Population dynamics and potential yield of three species of giant winkles in the Western Cape, South Africa. African Journal of Marine Science. 24:161-83.

[33] Iglesias J, Fuentes L. (2014) Culture viability of Sardina pilchardus (Fish, Teleost): Preliminary results of growth in captivity up to 18 months. Scientia Marina. 78(3):3715.

[34] Begossi A, Salivonchyk SV, Araujo LG, Andreoli TB, Clauzet M, Martinelli CM, Ferreira AG, Oliveira LE, Silvano RA. (2011) Ethnobiology of snappers (Lutjanidae): target species and suggestions for management. Journal of Ethnobiology and Ethnomedicine. 7(1):11.

[35] Navarro Peraza, Rosa \& Osuna-Ruiz, Idalia \& LugoSanchez, Maria \& Martínez-Montaño, Emmanuel \& Ramírez-Suárez, Juan \& Burgos-Hernández, Armando \& Salazar-Leyva, Jesús.(2020) Structural and biological properties of protein hydrolysates from seafood byproducts: a review focused on fishery effluents. Food Science and Technology (Campinas). 1-5. 10.1590/fst.24719.

[36]Lapa-Guimarães J, de Felício PE, Guzmán ES. (2005) Chemical and microbial analyses of squid muscle (Loligo plei) during storage in ice. Food chemistry. 91(3):477-83.

[37]Burri L, Hoem N, Banni S, Berge K. (2012)Marine omega-3 phospholipids: metabolism and biological activities. International Journal of Molecular Sciences. 13(11):15401-19.

[38] Olgunoglu IA. (2017) Review on omega-3 (n-3) fatty acids in fish and seafood. Journal of biology, agriculture and healthcare. 7(12):37-45.

[39] Pasantes-Morales H, Quesada O, Alcocer L, Sánchez Olea R. (1989) Taurine content in foods. Nutr Rep Int. ;40:793-801.

[40] García-Chavarría M, Lara-Flores M. (2013) The use of carotenoid in aquaculture. Research Journal of Fisheries and Hydrobiology. 8(2):38-49.

[41] Kundam DN, Acham IO, Girgih AT. (2018) Bioactive compounds in fish and their health benefits. Asian Food Science Journal. 28:1-4.

[42] Gonçalves AA. (2009) Ozone: an emerging technology for the seafood industry. Brazilian archives of Biology and Technology. 52(6):1527-39.

[43] Almeida, Adelaide. (2015). Phage therapy in aquaculture. 10.13140/2.1.3191.8401.

[44] Anyasi TA, Jideani AI, Edokpayi JN, Anokwuru CP. (2017) Application of Organic Acids in food preservation. Organic Acids, Characteristics, Properties and Synthesis; Vargas, C., Ed. :1-47.

[45]Ucak I, Gokoglu N, Kiessling M, Toepfl S, Galanakis CM. (2019) Inhibitory effects of high pressure treatment on microbial growth and biogenic amine formation in marinated herring (Clupea harengus) inoculated with Morganella psychrotolerans. LWT. 99:50-6..

[46] Soccol MC, Oetterer M. (2003) Use of modified atmosphere in seafood preservation. Brazilian archives of biology and technology. Dec;46(4):569-80.

[47] Cho HO, Kwon JH, Byun MW, Lee MK. (1985) Preservation of fried fish meat paste by irradiation. 
International Journal of Engineering Applied Sciences and Technology, 2020

Vol. 5, Issue 7, ISSN No. 2455-2143, Pages 75-82

Published Online November 2020 in IJEAST (http://www.ijeast.com)

Korean Journal of Food Science and Technology. 17(6):474-81.

[48] Thakur A, Anju KD, Thakur N, Hamid H, Chauhan M, Gautam S. (2019) An Introduction to Seafood and Recent Advances in the Processing of Seafood Products. 10:169180. 10.15515/iaast.0976-4828.10.2.169180. 